\title{
ИЗМЕНЕНИЕ КЛЮЧЕВЫХ ПАРАМЕТРОВ МЕТАБОЛИЗМА ЛИПИДОВ В ТКАНЯХ МОЗГА КРЫС ПРИ ПЕРМАНЕНТНОЙ ИШЕМИИ
}

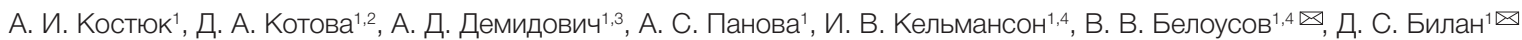 \\ ${ }^{1}$ Институт биоорганической химии имени М. М. Шемякина и Ю. А. Овчинникова, Москва, Россия \\ ${ }^{2}$ Биологический факультет, Московский государственный университет имени М. В. Ломоносова, Москва, Россия \\ ${ }^{3}$ Химический факультет, Московский государственный университет имени М. В. Ломоносова, Москва, Россия \\ ${ }^{4}$ Научно-исследовательский институт трансляционной медицины, \\ Российский национальный исследовательский медицинский университет имени Н. И. Пирогова, Москва, Россия
}

\begin{abstract}
Инсульт головного мозга является важнейшей проблемой современного человечества, миллионы людей ежегодно становятся жертвами этого недуга. Несмотря на масштабные исследования в этой области, до сих пор существует недостаток информации о патофизиологии ишемического инсульта. Тщательное изучение изменений биохимических показателей на раннем этапе заболевания позволит установить механизм его протекания и в будущем найти эффективное решение проблемы. Ключевая роль в патогенезе инсульта принадлежит липидам и молекулам, ассоциированным с их биосинтезом и поддержанием их функционального состояния. С одной стороны, при патогенезе инсульта происходит мощный окислительный стресс, который приводит к повреждению молекул, в том числе липидного состава. С другой стороны, из-за нехватки восстановительных эквивалентов останавливается биосинтез новых молекул взамен поврежденных. Целью работы было исследовать изменения в тканях мозга крыс при ишемии таких параметров, как концентрации общего холестерина, свободных жирных кислот (СЖК), малонового диальдегида (МДА), а также уровней восстановленного глутатиона (GSH) и общего НАДФ(H). В результате исследования выявлено, что через 24 ч с момента начала развития ишемии уровни СЖK, холестерина и GSH существенно снижаются, при этом уровень МДА, маркера перекисного повреждения липидов, увеличивается. Уровень общего пула НАДФ(Н) снижается в 2 раза уже через 6 ч с момента окклюзии сосуда.
\end{abstract}

Ключевые слова: ишемия, инсульт, перекисное окисление липидов, окислительный стресс, активные формы кислорода

Финансирование: работа выполнена при поддержке Российского научного фонда (грант № 17-15-01175).

Информация о вкладе авторов: Д. С. Билан и В. В. Белоусов планировали экспериментальную работу и писали текст статьи; Д. С. Билан, Д. А. Котова и И. В. Кельмансон осуществляли хирургические манипуляции с животными; А. И. Костюк, Д. А. Котова, А. Д. Демидович и А. С. Панова проводили биохимические измерения.

Соблюдение этических стандартов: эксперименты с животными выполняли в соответствии с требованиями Директивы 2010/63/ЕU Европейского парламента и совета Европейского союза от 22 сентября 2010 г. Протокол исследования (№ 237 от 14 сентября 2017 г.) был утвержден комиссией ИБХ РАН по контролю за содержанием и использованием животных.

$\longrightarrow$ Для корреспонденции: Всеволод Вадимович Белоусов Дмитрий Сергеевич Билан ул. Миклухо-Маклая, д. 16/10, г. Москва, 117997; vsevolod.belousov@gmail.com ул. Миклухо-Маклая, д. 16/10, г. Mосква, 117997; d.s.bilan@gmail.com Статья получена: 12.12.2018 Статья принята к печати: 26.02.2019 Опубликована онлайн: 09.03.2019

DOI: 10.24075/vrgmu.2019.008

\section{LIPID METABOLIC CHANGES IN RAT BRAIN DURING PERMANENT CEREBRAL ISCHEMIA}

Kostyuk $\mathrm{Al}^{1}$, Kotova $\mathrm{DA}^{1,2}$, Demidovich $\mathrm{AD}^{1,3}$, Panova $A S^{1}$, Kelmanson $\mathrm{IV}^{1,4}$, Belousov $\mathrm{W}^{1,4} \square$, Bilan $\mathrm{DS}^{1} \otimes$

Shemyakin-Ovchinnikov Institute of Bioorganic Chemistry, Russian Academy of Sciences, Moscow, Russia

${ }^{2}$ Lomonosov Moscow State University, Moscow, Russia

${ }^{3}$ Lomonosov Moscow State University, Moscow, Russia

${ }^{4}$ The Research Institute for Translational Medicine,

Pirogov Russian National Research Medical University, Moscow, Russia

With each year, millions of people remain targeted by brain stroke, it still is by all means a global concern of the mankind. Despite all efforts to understand this disease better, there is still a lack of information on pathophysiology of ischemic stroke. Scrutinized data on biochemical changes at early stages of ischemia may help understand the mechanisms of the disorder and possibly reveal ways to finding the cure. The key role in the pathogenesis of stroke belongs to lipids as well as to the molecules associated with their biosynthesis and functionality. On the one hand, stroke evokes a deep oxidative stress leading to damage to biomolecules including lipids while on the other hand, due to the lack of reducing equivalents, the cellular biosynthesis processes are interrupted. The focus of this work was to study the changes taking place in the tissues of rat brain as a result of ischemia including estimation of levels of total cholesterol, FFA, MDA, GSH, and NADP(H). It was shown that in 24 hours from the onset of ischemia, there was a significant decrease in levels of FFA, total cholesterol and GSH, and an increase in the level of MDA, a marker of lipid peroxidation. $\operatorname{NADP}(\mathrm{H})$ pool level decreases twice in 6 hours from MCAO.

Keywords: ischemia, stroke, lipid peroxidation, oxidative stress, reactive oxygen species

Funding: the work was supported by the Russian Science Foundation Grant 17-15-01175

Author contribution: Bilan DS and Belousov W were responsible for the study design and drafting the manuscript; Bilan DS, Kotova DA and Kelmanson IV performed surgeries; Kostyuk Al, Kotova DA, Demidovich AD and Panova AS performed biochemical measurements.

Compliance with ethical standards: experiments were carried out in compliance with the Directive 2010/63/EU of the European Parliament and the European Council, dated September 22, 2010. All experimental procedures were approved by The Animal Care and Use Committee of the Institute of Bioorganic Chemistry, RAS on September 14, 2017, Ref. No.237.

Correspondence should be addressed: Vsevolod V. Belousov

Received: 12.12.2018 Accepted: 26.02.2019 Published online: 09.03.2019

DOI: $10.24075 /$ brsmu.2019.008 
По данным Всемирной организации здравоохранения, инсульт находится на втором месте в числе заболеваний, приводящий к летальному исходу. Более 15 млн людей во всем мире ежегодно становятся жертвами этой болезни, 6 млн из них погибает, 5 млн становятся нетрудоспособными [1]. Ишемический инсульт возникает вследствие стеноза или закупорки сосудов головного мозга, что приводит к нарушению кровоснабжения и быстрому повреждению тканей [2].

Исследования последних лет выявили изменения биохимии клеток мозга, происходящих при развитии инсульта. В частности, состояние гипоксии ткани способствует возрастанию внеклеточной концентрации важного нейромедиатора глутамата и его связыванию с глутаматными рецепторами [3], что приводит к резкому увеличению концентрации внутриклеточного кальция. Неконтролируемая регуляция кальция приводит к активации кальций-зависимых белков и глобальному нарушению регуляции клеточных каскадов [4]. Одновременно с этими происходят другие биохимические процессы, которые приводят к истощению энергетических запасов клетки, изменяют внутриклеточный ионный состав, снижают $\mathrm{pH}$ цитоплазмы [5, 6]. На более поздних стадиях патогенеза происходит повреждение ДНК, изменение белкового и липидного состава [7]. Все описанные выше процессы приводят $\mathrm{k}$ дисфункции митохондрий и массовой клеточной гибели [8].

Липиды составляют около половины сухой массы мозговой ткани и выполняют важные структурные и метаболические функции. Глицерофоосфолипиды и сфинголипиды составляют основную часть клеточных мембран; холестерин входит в состав липидных рафтов структур, которые влияют на текучесть мембраны, регулируют синаптическую передачу. Поскольку липиды не проходят через гемато-энцефалический барьер, их биосинтез в нервных клетках происходит de novo. Одним из ключевых участников синтеза является НАДФ $(\mathrm{H})$ основной донор восстановительных эквивалентов в реакциях анаболизма.

При ишемии-реперфузии ткани образуются активные формы кислорода (АФК) [9], которые приводят к окислению липидного состава, что обусловливает увеличение в клетке продуктов перекисного окисления липидов, например, малонового диальдегида, 4-гидроксиноненала [10]. Эти соединения могут быть использованы в качестве маркеров окислительного стресса.

В ответ на внутриклеточное повышение АФК активируются антиоксидантные системы защиты. Глутатион играет ключевую роль в реакциях тиолдисульфидного обмена клетки [11, 12]. При этом поддержание определенного редокс-состояния пула глутатиона опосредовано НАДФ(Н) зависимыми системами [12]. Таким образом, оба эти параметра играют первостепенную роль в регуляции процессов, направленных против окислительного стресса в условиях ишемического повреждения ткани [13].

Целью настоящего исследования стало определение наиболее важных биохимических параметров, касающихся липидного обмена, в тканях мозга крыс через разные промежутки времени с момента начала развития ишемического повреждения. Оценку уровней метаболитов производили с помощью коммерческих наборов и по стандартным протоколам (МДА, НАДФ(Н)) $[14,15]$.

\section{МАТЕРИАЛЫ И МЕТОДЫ}

\section{Животные и хирургические манипуляции}

Работу проводили на самцах крыс линии Wistar из питомника лабораторных животных «Пущино» весом 280-330 г. Крыс содержали в виварии ИБХ РАН по три особи в пластмассовых клетках со свободным доступом к воде и пище. Экспериментальная работа (хирургические операции и биохимические тесты) была проведена в течение месяца (июнь 2018 г.).

Окклюзию средней мозговой артерии проводили по ранее описанному протоколу [16]. Использовали ингаляционный наркоз: смесь воздуха с изофлураном (Aeppaн, Baxter; США). Используемые концентрации: 5\% - введение в наркоз; 2\% - поддержание во время хирургической операции.

Для обезболивания использовали кетопрофен 5 мг/кг подкожно (Ketonal, Sandoz; Швейцария), местное обезболивание проводили с помощью 2\%-го новокаина.

В работе использовали готовые окклюдеры диаметром 0,185 мм (Doccol; CШA; кат. No 403756PK10Re).

\section{Подготовка ткани}

Для проведения биохимических тестов животные случайным образом были поделены на пять экспериментальных групп по четыре особи в каждой. Контрольная группа включала в себя интактных животных. В остальных четырех группах животным было проведено моделирование перманентной ишемии левого полушария мозга путем окклюзии средней мозговой артерии. После этого биохимический анализ ткани проводили через 1 ч с момента окклюзии сосуда (2-я группа), 3 ч (3-я группа), 6 ч (4-я группа) и через 24 ч (5-я группа).

Для анализа мозг каждого животного был извлечен с последующим удалением мозжечка и обонятельных луковиц. Ткань помещали в предварительно охлажденную фарфоровую ступку и добавляли жидкий азот, после чего тщательно растирали пестиком. Полученный материал взвешивали и хранили при температуре $-70^{\circ} \mathrm{C}$.

\section{Измерение концентрации свободных жирных кислот}

Содержание свободных жирных кислот в образцах мозга определяли при помощи коммерческого набора согласно инструкции производителя (Free Fatty Acid Quantification Assay Kit; Abcam, Англия). Общая схема анализа устроена следующим образом. Сначала свободные жирные кислоты переводят в ацил-КоА под действием ацил-КоА синтетазы. Затем специсичный фрермент окисляет полученные тиоэфиры, что сопровождается восстановлением бесцветной пробы с образованием флуоресцирующего соединения (Ех. 535 нм; Em. 587 нм).

Ткань размораживали на льду, после чего перетирали в 200 мкл 1\% Triton X-100 в чистом хлороформе при помощи ручного гомогенизатора Поттера. Полученный гомогенат инкубировали на льду в течение 30 мин для увеличения эффективности экстракции. Далее образцы центрифугировали в течение 10 мин на максимальной скорости, после чего отбирали органическую фазу. Для избавления от хлороформа препараты сначала сушили при $+50{ }^{\circ} \mathrm{C}$ в вытяжном шкафу в течение часа, после чего помещали их в вакуумную сушку еще на один час. 
Полученную липидную фракцию растворяли в 200 мкл Fatty Acid Assay Buffer, активно перемешивая.

Для анализа использовали аликвоты объемом от 10 до 40 мкл. Общий объем пробы доводили до 50 мкл раствором Fatty Acid Assay Buffer. Параллельно готовили ряд стандартных растворов с известными концентрациями пальмитиновой кислоты для последующего построения калибровочного графика. В каждую пробу реакционной смеси добавляли по 2 мкл ACS Reagent (препарат с ацилКоА синтетазной активностью), после чего инкубировали при +37 ${ }^{\circ} \mathrm{C}$ в течение 30 мин. По окончании данного времени ко всем образцам добавляли по 50 мкл смеси следующего состава: 45,6 мкл Assay Buffer; 0,4 мкл Fatty Acid Probe; 2 мкл Enzyme Mix; 2 мкл Enchancer. Образцы перемешивали и вновь инкубировали при $+37^{\circ} \mathrm{C}$ в течение 30 мин.

Флуоресцентный сигнал каждой пробы регистрировали c помощью прибора Tecan Reader Infinite ${ }^{\circledR} 200$ PRO (Tecan; Швейцария). Параметры измерения: Em. 587 нм, Ех. 535 нм. По показаниям образцов стандартного ряда определяли зависимость интенсивности флуоресценции от количества свободных жирных кислот в пробе. После этого рассчитывали значения в каждой экспериментальной пробе. Полученные значения нормировали на массу ткани.

\section{Измерение концентрации холестерина}

Содержание общего уровня холестерина (как свободного, так и в составе эфиров) в образцах мозга определяли с помощью коммерческого набора согласно инструкции производителя (Cholesterol/Cholesteryl Ester Detection Kit; Abcam, Англия). Принцип анализа основан на окислении холестерина специфическим ферментом холестерин-дегидрогеназой, которое сопровождается восстановлением НАДН. Последний в свою очередь реагирует с чувствительным красителем с образованием продукта, характеризующегося поглощением в области 450 нм.

Ткань размораживали на льду, после чего перетирали ее при помощи ручного гомогенизатора Поттера в 200 мкл смеси следующего состава: 7 частей хлороформа, 11 частей изопропилового спирта, 0,1 часть 10\% NP-40 в воде. Полученный гомогенат центрифугировали в течение 10 мин на максимальной скорости, после чего отбирали органическую фазу. Для того чтобы избавиться от хлороформа препараты сначала сушили при $+50{ }^{\circ} \mathrm{C}$ в вытяжном шкафу в течение часа, после чего помещали их в вакуумную сушку еще на один час. Полученную липидную фракцию растворяли в 200 мкл Cholesterol Assay Buffer, интенсивно перемешивая.

Для анализа отбирали аликвоты объемом от 10 до 40 мкл. Общий объем доводили до 50 мкл раствором Cholesterol Assay Buffer. Параллельно готовили стандартный ряд растворов с известной концентрацией холестерина для построения калибровочного графика. Далее к реакционной смеси каждой пробы добавляли 2 мкл Esterase (препарат, гидролизующий эфиры холестерина), тщательно перемешивали и инкубировали при $+37^{\circ} \mathrm{C}$ в течение 30 мин. По окончании данного времени ко всем образцам добавляли по 48 мкл смеси следующего состава: 44 мкл Cholesterol Assay Buffer, 2 мкл Substrate Mix, 2 мкл Cholesterol Enzyme Мix. Образцы перемешивали и вновь оставляли инкубироваться при $+37^{\circ} \mathrm{C}$ в течение 30 мин для развития окраски.

Значения сигнала в каждой пробе регистрировали с помощью планшетного ридера Tecan Reader Infinite ${ }^{\circledR}$
200 PRO (Tecan; Швейцария), измеряя поглощение образцов в области 450 нм. По образцам стандартного ряда определяли зависимость сигнала от количества холестерина в пробе. Все рассчитанные значения экспериментальных проб нормировали на исходную массу отобранной ткани.

\section{Измерение концентрации общего пула НАДФ(Н)}

Содержание НАДФ $(\mathrm{H})$ в образцах мозга определяли при помощи анализа, основанного на использовании нитросинего тетразолия (NBT) и феназинметасульфата (PMS). В данной системе НАДФН выступает в качестве донора электронов, восстанавливая PMS, который передает электроны NBT с образованием формазана. Формазан обладает поглощением при длине волны 620 нм. Для визуализации окисленного НАДФ' использовали ферментативную реакцию, в ходе которой глюкозо-6фосфатдегидрогеназа окисляет глюкозо-6-фосфрат, что сопровождается восстановлением кофактора.

Около 300 мг ткани размораживали на льду, после чего перетирали ее при помощи ручного гомогенизатора Поттера в 1,5 мл предварительно охлажденного карбонатного бусрера (100 мM Na${ }_{2} \mathrm{CO}_{3}, 20 \mathrm{MM} \mathrm{NaHCO}$, 20 мМ никотинамид). Образцы центрифугировали при $+4{ }^{\circ} \mathrm{C}$ в течение 5 мин на максимальной скорости. От супернатанта отбирали 10 мкл для определения концентрации белка в растворе, а оставшийся объем подвергали дополнительной очистке на колонках Amicon ${ }^{\circledast}$ Ultra 0,5 mL 10K (Merck Millipore; Германия) согласно протоколу производителя.

Для анализа в лунки 96-луночного планшета добавляли по 10 мкл каждого образца. Параллельно готовили стандартный ряд растворов с известным количеством НАДФН. Объем проб доводили до 100 мкл при помощи реакционной смеси следующего состава (из расчета на 10 реакций): 540 мкл MQ, 100 мкл 1 M TRIS-HCl буфера (pH 8,0), 50 мкл 10 мM NBT, 150 мкл 10 мM PMS, 50 мкл 100 мM раствора ЭДТА, 10 мкл 100 мМ глюкозо-6-фосффата. Пробы инкубировали в термостате при $+37^{\circ} \mathrm{C}$ в течение 5 мин, после чего запускали реакцию добавлением 1 мкл 250 ед./мл глюкозо-6-фросфатдегидрогеназы.

Интенсивность поглощения при 620 нм в каждой пробе регистрировали с помощью планшетного ридера Tecan Reader Infinite ${ }^{\circledast} 200$ PRO (Tecan; Швейцария) в течение 10 мин. Каждая проба была в двух повторах, в одном из случаев мы не добавляли фермент для определения фонового образования формазана под действием компонентов клеточных лизатов. По образцам стандартного ряда определяли зависимость скорости реакции от количества НАДФН в образце. Полученный калибровочный график использовали для определения общей концентрации НАДФ(Н) в экспериментальных пробах. Полученные значения нормировали на концентрацию белка.

\section{Измерение концентрации малонового диальдегида как маркера перекисного окисления липидов}

Для определения интенсивности перекисного окисления липидов в исследуемых образцах использовали классический TBARS-анализ с модификациями. В ходе данной процедуры малоновый диальдегид, являющийся одним из основных продуктов перекисного окисления липидов, взаимодействует с двумя молекулами 2-тиобарбитуровой кислоты (ТВА) 
с образованием окрашенного соединения, интенсивно поглощающего свет при 532 нм.

Около 100 мг ткани размораживали на льду, после чего перетирали ее при помощи ручного гомогенизатора Поттера в 750 мкл предварительно охлажденной воды степени очистки MQ. В воду добавляли 5 мкл бутилированного гидрокситолуола, растворенного в метаноле в концентрации 10\% (w/v), для предотвращения окисления образцов кислородом воздуха. Далее образцы центрифугировали при $3000 \times \mathrm{g}$ и $+4^{\circ} \mathrm{C}$ в течение 15 мин для получения растворимой фракции, содержащей клеточные мембраны. На этой стадии от супернатанта отбирали 10 мкл для определения концентрации белка, после чего к 350 мкл образца добавляли 250 мкл 40\% трихлоруксусной кислоты для осаждения белков, интенсивно перемешивая пробу. Далее образцы повторно центрифугировали при $3000 \times \mathrm{g} \mathrm{и}+4{ }^{\circ} \mathrm{C}$ в течение $15 \mathrm{мин.}$

Для анализа от образцов отбирали по 500 мкл супернатанта, после чего смешивали их с 500 мкл 0,67\% TBA в 0,05 N NaOH. Для приготовления ряда стандартных растворов использовали 0,5 мМ 1,1,3,3,-тетраметоксипропан (ТМР), последовательно растворенный в 1 мл 96\% этилового спирта и 49 мл MQ. Стандартные растворы смешивали с 500 мкл 0,67\% ТВА в 0,05 N NaOH, после чего все образцы инкубировали в термостате при $+100^{\circ} \mathrm{C}$ в течение 15 мин. После инкубации в 96-луночный планшет добавляли по 200 мкл каждого образца и регистрировали поглощение при 532 нм с помощью планшетного ридера Tecan Reader Infinite ${ }^{\circledR} 200$ PRO (Tecan; Швейцария). По образцам стандартного ряда строили калибровочный график и определяли количество малонового диальдегида в каждой экспериментальной пробе. Полученные значения нормировали на концентрацию белка.

\section{Измерение концентрации восстановленной формы глутатиона (GSH)}

Содержание восстановленной (GSH) формы глутатиона в образцах мозга определяли при помощи коммерческого набора согласно инструкции производителя (GSH/GSSG Ratio Detection Assay Kit, Fluorometric-Green, Abcam, Англия). Принцип анализа основан на взаимодействии GSH c бесцветным красителем Thiol Green, в ходе чего последний приобретает флуоресцентные свойства (Ех. 490, Em. 520).

Ткань размораживали на льду, после чего перетирали ее при помощи ручного гомогенизатора Поттера в 400 мкл фоссратно-солевого бусрера (pH 7,4), содержащего 0,5\% NP-40. Полученные гомогенаты центрифугировали на максимальной скорости при $+4{ }^{\circ} \mathrm{C}$ в течение 15 мин. На следующем этапе пробы депротеинизировали добавлением 1/5 объема 100\% (w/v) трихлоруксусной кислоты (ТХУ). После интенсивного перемешивания и инкубации на льду в течение 10 мин образцы вновь центрифугировали при $12000 \times g$ и $+4{ }^{\circ} \mathrm{C}$ в течение 5 мин. ТХУ нейтрализовали путем добавления в образцы раствора $\mathrm{NaHCO}_{3}$. Наконец, проводили последнее центрифугирование при 13000 × g и $+4{ }^{\circ} \mathrm{C}$ в течение 15 мин.

Для анализа супернатанты разводили в 10 раз раствором Assay Buffer, после чего в 96-луночный планшет вносили по 50 мкл раствора каждого образца. Параллельно готовили стандартный ряд растворов с заданными концентрациями GSH. Далее к пробам добавляли 50 мкл раствора Thiol Green, разбавленного в 100 раз Assay Buffer. После чего пробы инкубировали в темноте в течение часа.
Флуоресцентный сигнал проб регистрировали с помощью планшетного ридера Tecan Reader Infinite ${ }^{\circledR} 200$ PRO (Tecan; Швейцария). По образцам стандартного ряда определяли зависимость интенсивности фрлуоресценции от количества глутатиона в пробе. По калибровочному графику определяли количество GSH в каждой пробе. Полученные значения нормировали на исходную массу отобранной ткани.

\section{Измерение концентрации белка в препаратах тканей мозга}

Для определения концентрации белка использовали коммерческий набор (Bicinchoninic Acid Protein Assay Kit; Sigma-Aldrich, Германия). Для построения калибровочного графика в каждой серии экспериментов готовили стандартный ряд растворов с известной концентрацией белка бычьего сывороточного альбумина. В пробы добавляли смесь, содержащую 1 часть 4\% (w/v) пентагидрата сульфата меди (II) и 50 частей раствора, содержащего бицинхониновую кислоту. Далее образцы инкубировали 30 мин при $+37^{\circ} \mathrm{C}$.

C помощью прибора Tecan Reader Infinite ${ }^{\circledast} 200$ PRO (Tecan; Швейцария) измеряли поглощение образцов в области 562 нм. По калибровочному графику определяли концентрацию белка в каждой анализируемой пробе.

\section{РЕЗУЛЬТАТЫ ИССЛЕДОВАНИЯ}

Были определены изменения общего уровня НАДФ(Н) в тканях больного полушария мозга крыс через разные промежутки времени с момента начала развития перманентной ишемии. Значительное изменение данного параметра наблюдается уже через 6 ч после окклюзии средней мозговой артерии. При норме 10,64+/-0,57 мкмоль/мг белка, измеренной в тканях здоровых животных, уровень НАДФ $(H)$ в области повреждения снизился до значения 4,45+/-0,79 мкмоль/мг белка. Через сутки этот параметр изменился примерно в 7 раз, составив 1,57+/-0,46 мкмоль/мг белка (рис. 1А).

Поскольку НАДФ $(\mathrm{H})$ вовлечен во многие биосинтетические процессы клеток, в том числе связанные с метаболизмом липидов, мы ожидали зарегистрировать в тканях существенное падение холестерина и жирных кислот. Действительно, уровень общего холестерина (как свободного, так и в составе эфиров) начинал снижаться через 6 ч с момента начала развития патологии: значение 7,29+/-0,20 мкг/мг ткани здоровых животных изменялось до 6,85+/-0,1 мкг/мг ткани. Через сутки в клетках поврежденного полушария уровень холестерина продолжал снижаться до значения 5,95+/-0,4 мкг/Мг ткани (рис. 1Б). В первые 3 ч патогенеза разницы в уровне холестерина зафиксировано не было. Однако следует отметить, что наибольшая вариабельность значений была обнаружена в группе животных после 3 ч с момента окклюзии. Возможно, к данному моменту времени у некоторых животных в группе уровень холестерина в клетках поврежденной области начинал снижаться. При определении уровня свободных жирных кислот (СЖК) в тканях мозга нам удалось зафиксировать выраженную разницу лишь через сутки. Показатель 0,31+/-0,01 нмоль/мг, свойственный для здоровой ткани, через сутки снизился до значения 0,25+/-0,003 нмоль/мг (рис. 1В).

Малоновый диальдегид (МДА) является одним из маркеров перекисного окисления липидов. Поэтому в 
клетках ткани мозга по мере снижения биосинтетических процессов должны накапливаться также продукты деградации, вызванные повреждением ткани. Однако выраженное увеличение концентрации МДА в тканях больного полушария крыс было зафиксировано лишь на следующие сутки. Уровень МДА определяли также в тканях здоровых животных (846,23+/-63,41 пмоль/мг белка), поскольку процессы деградации молекул происходят не только при развитии патологических процессов, но и при нормальном функционировании клеток. Патологическое состояние наступает, когда клетки не могут справиться с повреждением и восполнить нефункциональные молекулы синтезом новых. Через 24 ч ишемии в тканях мозга концентрация МДА увеличилась до 1272,61+/-124,47 пмоль/мг белка (рис. 1Г). В это же время в поврежденной области происходила массовая гибель клеток, которую можно визуализировать прокрашиванием срезов мозга специальным красителем, например, 2,3,5-трифенилтетразолием хлористым.

Пул глутатиона определяет общее редокс-состояние клеток. В частности, при окислительном повреждении белки антиоксидантных систем, например, глутатион пероксидазы, используют восстановленный глутатион для нейтрализации АФК. Поэтому поддержание редоксстатуса глутатиона является важнейшей задачей клетки. При этом поддержание уровня восстановленного глутатиона в реакции глутатионредуктазы требует наличия в системе восстановленного пула НАДФН. В течение первых 6 ч с момента наступления ишемии изменений уровня восстановленного глутатиона в тканях мозга крыс зафиксировано не было. Через сутки этот показатель уменьшался примерно в 3 раза по сравнению с тканью здоровых животных, со значения 35,1 мкг/кг до 11,8 мкг/кг ткани, соответственно (рис. 1Д).

Таким образом, исследуемые нами биохимические параметры значительно изменялись лишь через сутки с момента начала развития патологии. Исключение составляет лишь общий уровень НАДФ(Н), который оказался наиболее чувствителен к ишемии ткани и существенно снижался уже через 64 .

По оси ОХ представленных грасиков указаны временные интервалы получения образцов тканей с момента окклюзии средней мозговой артерии животных. Планки погрешностей соответствуют стандартной ошибке среднего. В каждой группе по 4 особи.

\section{ОБСУЖЖДЕНИЕ РЕЗУЛЬТАТОВ}

Ишемическое повреждение мозга представляет собой выраженный стресс, сопровождающийся повреждением биологических структур на молекулярном и клеточном уровнях. Защита тканей различных организмов от последствия ишемического повреждения реализуется на нескольких уровнях, а именно на стадиях предотвращения
A

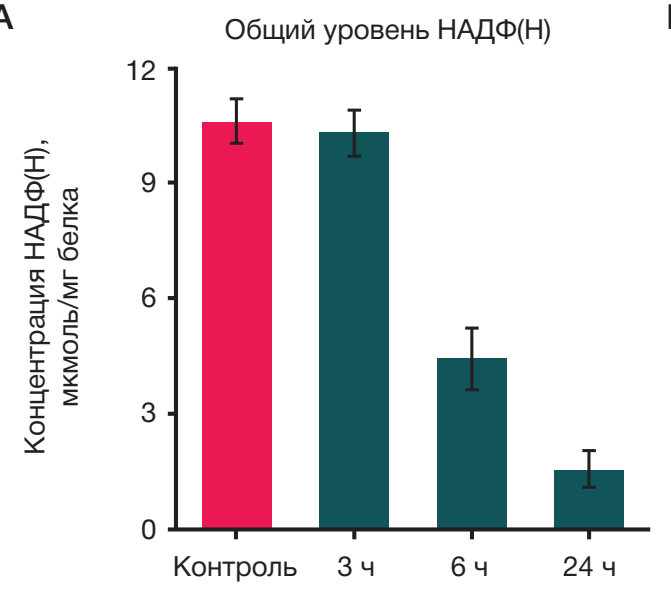

Б

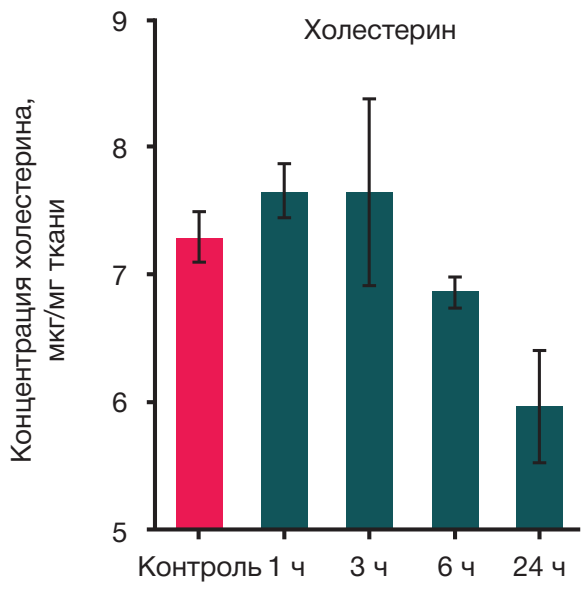

Д

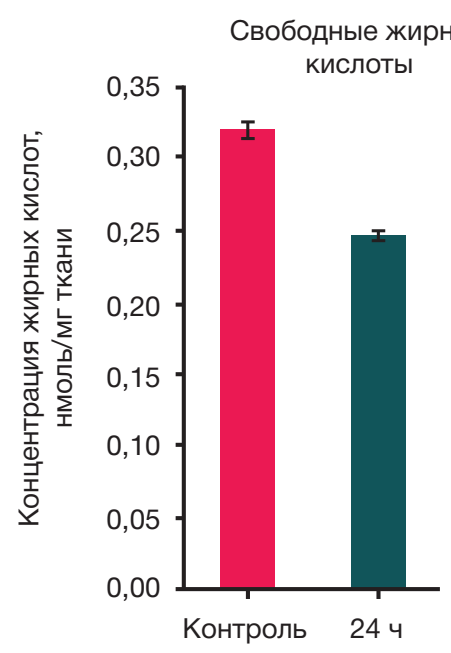

Малоновый диальдегид

$\Gamma$

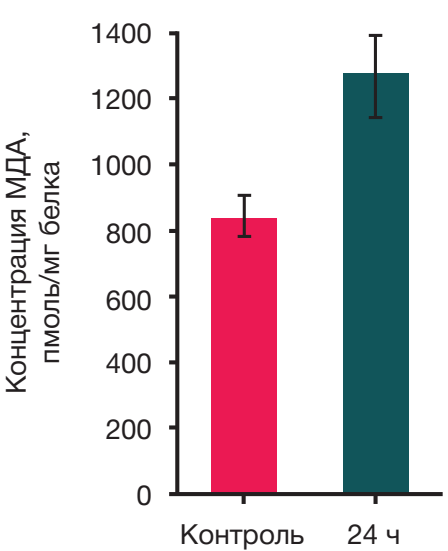

Восстановленный глутатион, GSH

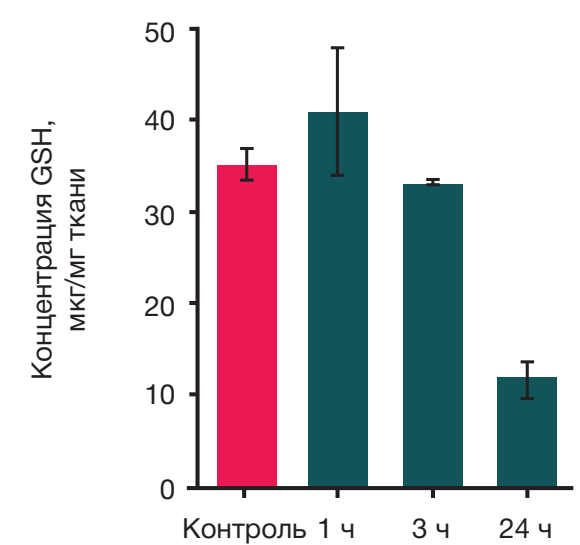

Рис. 1. Изменение биохимических параметров тканей мозга крыс через разные промежутки времени с момента развития перманентной ишемии Представлена динамика изменения концентрации общего уровня НАДФ(Н) (А), общего холестерина (Б), свободных жирных кислот (В), малонового диальдегида (Г), восстановленного глутатиона (Д) 
повреждений, репарации повреждений и полной замены структур, утративших функциональность.

Известно, что ишемический инсульт характеризуется избыточной и нерегулируемой продукцией АФК [9], которые представляют собой высокореакционные соединения, вступающие в широкий спектр взаимодействий с компонентами клетки. Так, одной из основных мишеней АФК в клетке являются липиды, находящиеся как в свободной форме, так и входящие в состав мембран. Перекисное окисление липидов является одним из распространенных процессов взаимодействия липидов с АФК. Данный процесс представляет собой радикальную цепную реакцию, конечными продуктами которой являются ковалентные агрегаты липидов, а также гидроперекиси липидов и эндопероксиды липидов, образующиеся в присутствии кислорода [10]. Последние, в свою очередь, вступают во внутримолекулярные перегруппировки с последующей фрагментацией углеводородных хвостов. Именно поэтому окислительный стресс в липидной фазе приводит к увеличению концентрации низкомолекулярных карбонильных соединений, таких как малоновый диальдегид (МДА). Большая часть методов, направленных на выявление окислительного стресса, так или иначе базируется на регистрации соединений данного класса $[17,18]$

Взаимодействие липидов с активными формами кислорода может приводить к высвобождению свободных жирных кислот. Кроме того, гибель клеток в очагах ишемии сопровождается также гидролизом липидов [19]. Известно, что свободные жирные кислоты могут подвергаться автоокислению, кроме того, метаболизм арахидоновой кислоты по циклооксигеназному пути включает в себя гидропероксиды липидов и приводит непосредственно к образованию радикалов кислорода [10, 20]. В конечном счете, перечисленные факторы способствуют еще более выраженному процессу перекисного окисления.

На практике во многих исследованиях с участием пациентов или с использованием лабораторных животных детектируют уровень МДА в крови. Есть данные о том, что в первые 24 часа после ишемии уровень малонового диальдегида значительно повышается, и высокая концентрация сохраняется на протяжении 7 дней [21], показана корреляция данного параметра со смертностью пациентов, переживших инсульт. Оценка концентрации МДА в клетках головного мозга при ишемическом инсульте может дать ценную информацию о степени поражения тканей [22].

В нашей работе была использована модель перманентной окклюзии средней мозговой артерии крыс. В данных условиях зафиксировать детектируемое увеличение концентрации малонового диальдегида удалось лишь через 24 часа с момента окклюзии. Для получения полной картины происходящего в дальнейшем необходимо провести подобного рода исследования на модели ишемии-реперфузии, подразумевающей восстановление кровотока в поврежденной области. Считается, что именно реперфузия является основным мощным источником генерации АФК. Поэтому можно предположить, что гибель клеток при перманентной ишемии происходит главным образом не из-за перекисного окисления липидов. При этом очаг мертвой ткани в данной системе визуализируется уже через несколько часов с момента окклюзии сосуда. В то же время используемый нами подход TBARSанализа крайне подвержен артефактам, вносимым на стадии пробоподготовки. Добавление антиоксидантов по типу бутилированного гидрокситолуола позволяет снизить образование малонового диальдегида под действием атмосферного кислорода, однако не предотвращает его полностью. Таким образом, зарегистрировать незначительное повышение концентрации МДА на фоне контроля становится крайне затруднительным.

В качестве одного из маркеров редокс-состояния клеток использовали концентрацию восстановленного глутатиона (GSH). Так же как и в случае малонового диальдегида, мы не наблюдали изменения концентрации GSH в ходе активной фазы ишемического повреждения, однако его количество в ткани значительно падало спустя сутки после окклюзии. Поскольку восстановленный глутатион участвует в реакциях тиол-дисульфидного обмена, то при увеличении концентрации активных форм кислорода он переходит в окисленное состояние за счет активации ферментов антиоксидантной системы. Из этого следует, что заметное увеличение окисленных липидов и дальнейшая гибель клетки приводят к значительному уменьшению восстановленного глутатиона. Однако для однозначных выводов требуются дополнительные исследования, в том числе на модели ишемии-реперфузии. С одной стороны, продолжительное перекисное окисление может приводить к истощению пула GSH; с другой стороны, истощение пула GSH может приводить К тому, что перекисное окисление, которое до этого могло быть сдержано, начинает вызывать выраженный повреждающий эффект. Наконец, уменьшение концентрации GSH может происходить по причинам, не связанным с работой антиоксидантных систем в регионах мембран. Например, некротизация ткани в принципе будет сопровождаться неспособностью клетки поддерживать пул глутатиона в восстановленном состоянии из-за нарушения условий работы соответствующих ферментативных систем, а также недостатка восстанавливающих эквивалентов.

На исследуемой модели мы показали, что концентрация общего пула НАДФ(Н) снижается в 2 раза уже через 64 после окклюзии, а через 24 ч падение достигает 7 раз. Можно предположить, что снижение общего уровня НАДФ $(\mathrm{H})$ негативно сказывается на эффективности работы как антиоксидантных систем, так и анаболических процессов. Возможно, этот фактор вносит свой вклад в падение пула GSH и увеличение степени перекисного окисления липидов, о чем говорилось ранее.

Не все липиды, поврежденные в ходе перекисного окисления, могут быть подвержены репарации. Поэтому мы предполагаем, что в ходе ишемического повреждения мозга анаболические пути, направленные на синтез данных соединений, будут усилены для замены поврежденных компонентов новыми. Известно, что значение пула НАДФ(Н) напрямую связано с эффективностью биосинтеза жирных кислот и холестерина, поскольку данные метаболические пути требуют восстановительных эквивалентов. Как было сказано выше, на исследуемой модели мы наблюдали изменение общей концентрации пула НАДФ(Н), что может отразиться на эффективности обсуждаемых процессов.

Определению профиля изменения уровня свободных жирных кислот (СЖК) в плазме крови посвящено большое количество клинических и лабораторных исследований, поскольку данный параметр является потенциальным биомаркером раннего этапа ишемического инсульта. Во время инсульта происходит гидролиз фосфолипидов мозга, и в кровь высвобождаются СЖК, с чем, возможно, связано повышение их уровня в плазме в течение первых часов [23]. Также имеются данные, в которых показана корреляция уровня СЖК с тяжестью заболевания: 
чем выше значение параметра, тем тяжелее состояние пациента [24, 25]. В то же время изменения профиля жирных кислот в тканях головного мозга мало изучены, несмотря на их важную метаболическую роль.

В данной работе мы определяли уровень СЖК в тканях больного полушария крыс. Анализ образцов проводили через разные промежутки времени с момента окклюзии. Нам удалось зафиксировать значительное уменьшение параметра только через 24 ч после окклюзии; в острой фазе инсульта уровень СЖК совпадал с уровнем СЖК в контрольной группе. Таким образом, мы не обнаружили данных, которые бы очевидно свидетельствовали в пользу усиления синтеза жирных кислот для возмещения поврежденных компонентов мембран. Уменьшение концентрации свободных жирных кислот через сутки после окклюзии, по всей видимости, связано с гибелью клеток, которая сопровождается истощением пула НАДФ(Н), нарушением условий работы ферментов и другими факторами. На основе этого наблюдения можно предположить, что в модели перманентной ишемии крыс гидролизованные в ходе гибели клеток липиды не накапливаются в мозговой ткани.
Аналогичные данные получены и для концентрации холестерина, однако в этом случае наблюдаемое снижение значения параметра происходит раньше (уже через 6 ч с момента операции). Кроме того, концентрации холестерина и СЖК уменьшаются одинаково через 24 ч после окклюзии относительно исходного уровня метаболитов (в 1,24 раза для жирных кислот и в 1,27 раз для холестерина).

\section{ВЫВОДЫ}

На модели перманентной ишемии головного мозга были исследованы следующие параметры: концентрация общего холестерина, свободных жирных кислот (СЖК), малонового диальдегида (МДА), а также уровни восстановленного глутатиона (GSH) и общего НАДФ(H). В результате данного исследования было выявлено, что уровни СЖK, холестерина и GSH существенно снижаются через 24 ч с момента начала развития ишемии, при этом увеличивается уровень МДА, являющегося маркером перекисного повреждения липидов. Уровень общего пула НАДФ(Н) снижается в 2 раза уже через 6 ч с момента окклюзии сосуда.

\section{Литература}

1. World Health Organization. Top ten causes of death. Available from: http://www.who.int/mediacentre/factsheets/fs310/en/index.html (accessed August 19, 2012).

2. Hinkle JL, Guanci MM. Acute Ischemic Stroke Review. Journal of Neuroscience Nursing. 2007; 39 (5): 285-93. PubMed PMID: 17966295.

3. Krzyżanowska W, Pomierny B, Filip M, Pera J. Glutamate transporters in brain ischemia: to modulate or not? Acta Pharmacologica Sinica. 2014; 35 (4): 444-62. PubMed PMID: 24681894.

4. Berliocchi L, Bano D, Nicotera P. $\mathrm{Ca}^{2+}$ signals and death programmes in neurons. Philos Trans R Soc Lond B Biol Sci. 2005; 360 (1464): 2255-8. PubMed PMID: 16321795.

5. Klogeris T, Baines CP, Krenz M, Korthuis RJ. Ischemia/ Reperfusion. Compr Physiol. 2016; (7): 113-70 PubMed PMID: 28135002.

6. Kalogeris T, Baines CP, Krenz M, Korthuis RJ. Cell biology of ischemia/reperfusion injury. Int Rev Cell Mol Biol. 2012; (298): 229-317. PubMed PMID: 22878108.

7. Allen CL, Bayraktutan U. Oxidative Stress and Its Role in the Pathogenesis of Ischaemic Stroke. International Journal of Stroke. 2009; 4 (6): 461-70. PubMed PMID: 19930058.

8. Lesnefsky EJ, Chen Q, Tandler B, Hoppel CL. Mitochondrial dysfunction and myocardial ischemia-reperfusion: implications for novel therapies. Annual review of pharmacology and toxicology. 2017; (57): 535-65. PubMed PMID: 27860548.

9. Vanden Hoek TL, Li C, Shao Z, Schumacker PT, Becker LB. Significant levels of oxidants are generated by isolated cardiomyocytes during ischemia prior to reperfusion. J Mol Cell Cardiol. 1997; (29): 2571-83. PubMed PMID: 9299379.

10. Gaschler MM, Stockwell BR. Lipid peroxidation in cell death. Biochem Biophys Res Commun. 2017; 482 (3): 419-25. PubMed PMID: 28212725.

11. Gaucher C, Boudier A, Bonetti J, Clarot I, Leroy P, Parent M. Glutathione: Antioxidant Properties Dedicated to Nanotechnologies. Antioxidants (Basel). 2018; 7 (5): 62. PubMed PMID: 29702624.

12. Билан Д. С., Шохина А. Г., Лукьянов С. А., Белоусов В. В. Основные редокс-пары клетки. Биоорганическая химия. 2015; (41): 385-402.

13. Dringen R, Pawlowski PG, Hirrlinger J. Peroxide detoxification by brain cells. Journal of Neuroscience Research. 2004; 79 (1-2): 157-165. PubMed PMID: 15573410.

14. Garcia YJ, Rodrıguez-Malaver AJ, Penãloza N. Lipid peroxidation measurement by thiobarbituric acid assay in rat cerebellar slices. Journal of Neuroscience Methods. 2005; (144): 127-35. PubMed PMID: 15848246.

15. Charis WT, Scott MD. Single Extraction Method for the Spectrophotometric Quantification of Oxidized and Reduced Pyridine Nucleotides in Erythrocytes. Analytical Biochemistry. 1994; (222): 417-26. PubMed PMID: 7864367.

16. Uluc K, Miranpuri A, Kujoth GC, Akture E, Baskaya MK. Focal cerebral ischemia model by endovascular suture occlusion of the middle cerebral artery in the rat. J Vis Exp. 2011 Feb 5; (48). PubMed PMID: 21339721.

17. Gutteridge JMC, Halliwell B. The measurement and mechanism of lipid peroxidation in biological systems. Trends in Biochemical Sciences. 1990; 15 (4): 129-35. PubMed PMID: 2187293.

18. Ceconi C, Cargnoni A, Pasini E, Condorelli E, Curello S, Ferrari R. Evaluation of phospholipid peroxidation as malondialdehyde during myocardial ischemia and reperfusion injury. Am J Physiol. 1991; 260 (4 Pt 2): H1057-61. PubMed PMID: 2012211.

19. Bazan NG. Effects of ischemia and electroconvulsive shock on free fatty acid pool in the brain. Biochimica et Biophysica Acta (BBA) - Lipids and Lipid Metabolism. 1970; 218 (1): 1-10. PubMed PMID: 5473492

20. Braughler JM, Hall ED. Central nervous system trauma and stroke. I. Biochemical considerations for oxygen radical formation and lipid peroxidation. Free Radic Biol Med. 1989; (6): 289-301. Pubmed PMID: 266366.

21. Cojocaru IM, Cojocaru M, Sapira V, Ionescu A. Evaluation of oxidative stress in patients with acute ischemic stroke. Rom J Intern Med. 2013 Apr-Jun; 51 (2): 97-106. Pubmed PMID: 24294813.

22. Lorente L, Martin MM, Perez-Cejas A, Abreu-Gonzalez P, Ramos L, Argueso $\mathrm{M}$ et al. Association between total antioxidant capacity and mortality in ischemic stroke patients. Ann Intensive Care. 2016; 6 (1): 39. Pubmed PMID: 27107565.

23. Golovko SA, Golovko MI. Plasma Unesterified Fatty-Acid Profile Is Dramatically and Acutely Changed under Ischemic Stroke in the Mouse Model. Lipids. 2018; 52 (6): 641-645. PubMed PMID: 30206953.

24. Niu Z, Hu H, Tang F. High Free Fatty Acid Levels Are Associated with Stroke Recurrence and Poor Functional Outcome in Chinese Patients with Ischemic Stroke. J Nutr Health Aging. 2017; 21 (10): 
1102-1106. PubMed PMID: 29188867

25. Wang $X$, Feng A, Zhu C. Cerebrospinal fluid levels of free fatty acid associated with ischemic stroke recurrence and functional outcome. Neurol Sci. 2016; 37 (9): 1525-9. PubMed PMID: 27245354

\section{References}

1. World Health Organization. Top ten causes of death. Available from: http://www.who.int/mediacentre/factsheets/fs310/en/index. html (accessed August 19, 2012).

2. Hinkle JL, Guanci MM. Acute Ischemic Stroke Review. Journal of Neuroscience Nursing. 2007; 39 (5): 285-93. PubMed PMID: 17966295

3. Krzyżanowska W, Pomierny B, Filip M, Pera J. Glutamate transporters in brain ischemia: to modulate or not? Acta Pharmacologica Sinica. 2014; 35 (4): 444-62. PubMed PMID: 24681894.

4. Berliocchi L, Bano D, Nicotera P. $\mathrm{Ca}^{2+}$ signals and death programmes in neurons. Philos Trans R Soc Lond B Biol Sci. 2005; 360 (1464): 2255-8. PubMed PMID: 16321795.

5. Klogeris T, Baines CP, Krenz M, Korthuis RJ. Ischemia/ Reperfusion. Compr Physiol. 2016; (7): 113-70 PubMed PMID: 28135002.

6. Kalogeris T, Baines CP, Krenz M, Korthuis RJ. Cell biology of ischemia/reperfusion injury. Int Rev Cell Mol Biol. 2012; (298): 229-317. PubMed PMID: 22878108.

7. Allen $\mathrm{CL}$, Bayraktutan U. Oxidative Stress and Its Role in the Pathogenesis of Ischaemic Stroke. International Journal of Stroke. 2009; 4 (6); 461-70. PubMed PMID: 19930058

8. Lesnefsky EJ, Chen Q, Tandler B, Hoppel CL. Mitochondrial dysfunction and myocardial ischemia-reperfusion: implications for novel therapies. Annual review of pharmacology and toxicology. 2017; (57): 535-65. PubMed PMID: 27860548.

9. Vanden Hoek TL, Li C, Shao Z, Schumacker PT, Becker LB. Significant levels of oxidants are generated by isolated cardiomyocytes during ischemia prior to reperfusion. J Mol Cell Cardiol. 1997; (29): 2571-83. PubMed PMID: 9299379.

10. Gaschler MM, Stockwell BR. Lipid peroxidation in cell death. Biochem Biophys Res Commun. 2017; 482 (3): 419-25. PubMed PMID: 28212725.

11. Gaucher C, Boudier A, Bonetti J, Clarot I, Leroy P, Parent M. Glutathione: Antioxidant Properties Dedicated to Nanotechnologies. Antioxidants (Basel). 2018; 7 (5): 62. PubMed PMID: 29702624.

12. Bilan DS, Shohina AG, Lukjanov SA, Belousov W. Osnovnye redoks-pary kletki. Bioorganicheskaya himija. 2015; (41): 385402. Russian.

13. Dringen R, Pawlowski PG, Hirlinger J. Peroxide detoxification by brain cells. Journal of Neuroscience Research. 2004; 79 (1-2): 157-165. PubMed PMID: 15573410.

14. Garcia YJ, Rodrıguez-Malaver AJ, Penãloza N. Lipid peroxidation measurement by thiobarbituric acid assay in rat cerebellar slices. Journal of Neuroscience Methods. 2005; (144): 127-35. PubMed

PMID: 15848246

15. Charis WT, Scott MD. Single Extraction Method for the Spectrophotometric Quantification of Oxidized and Reduced Pyridine Nucleotides in Erythrocytes. Analytical Biochemistry. 1994: (222): 417-26. PubMed PMID: 7864367.

16. Uluc K, Miranpuri A, Kujoth GC, Akture E, Baskaya MK. Focal cerebral ischemia model by endovascular suture occlusion of the middle cerebral artery in the rat. J Vis Exp. 2011 Feb 5; (48). PubMed PMID: 21339721.

17. Gutteridge JMC, Halliwell B. The measurement and mechanism of lipid peroxidation in biological systems. Trends in Biochemical Sciences. 1990; 15 (4): 129-35. PubMed PMID: 2187293.

18. Ceconi C, Cargnoni A, Pasini E, Condorelli E, Curello S, Ferrari R. Evaluation of phospholipid peroxidation as malondialdehyde during myocardial ischemia and reperfusion injury. Am J Physiol. 1991; 260 (4 Pt 2): H1057-61. PubMed PMID: 2012211.

19. Bazan NG. Effects of ischemia and electroconvulsive shock on free fatty acid pool in the brain. Biochimica et Biophysica Acta (BBA) - Lipids and Lipid Metabolism. 1970; 218 (1): 1-10. PubMed PMID: 5473492.

20. Braughler JM, Hall ED. Central nervous system trauma and stroke. I. Biochemical considerations for oxygen radical formation and lipid peroxidation. Free Radic Biol Med. 1989; (6): 289-301. Pubmed PMID: 266366.

21. Cojocaru IM, Cojocaru M, Sapira V, Ionescu A. Evaluation of oxidative stress in patients with acute ischemic stroke. Rom $\mathrm{J}$ Intern Med. 2013 Apr-Jun; 51 (2): 97-106. Pubmed PMID: 24294813.

22. Lorente L, Martin MM, Perez-Cejas A, Abreu-Gonzalez P, Ramos L, Argueso $\mathrm{M}$ et al. Association between total antioxidant capacity and mortality in ischemic stroke patients. Ann Intensive Care. 2016; 6 (1): 39. Pubmed PMID: 27107565.

23. Golovko SA, Golovko MI. Plasma Unesterified Fatty-Acid Profile Is Dramatically and Acutely Changed under Ischemic Stroke in the Mouse Model. Lipids. 2018; 52 (6): 641-645. PubMed PMID: 30206953.

24. Niu Z, Hu H, Tang F. High Free Fatty Acid Levels Are Associated with Stroke Recurrence and Poor Functional Outcome in Chinese Patients with Ischemic Stroke. J Nutr Health Aging. 2017; 21 (10): 1102-1106. PubMed PMID: 29188867.

25. Wang X, Feng A, Zhu C. Cerebrospinal fluid levels of free fatty acid associated with ischemic stroke recurrence and functional outcome. Neurol Sci. 2016; 37 (9): 1525-9. PubMed PMID: 27245354 . 